\title{
Digital fabrication and revival craft in Latin America: \\ 2016 TAIPEI Alliance between designers and artisans
}

Pablo C. Herrera / Universidad Peruana de Ciencias Aplicadas / Lima / Peru

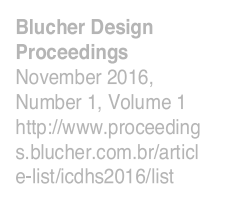

\begin{abstract}
Latin America has experienced scripting and digital fabrication, and the alliance between designers and artisans. Taking into account that the revival of crafts has proved very promising in Latin America (Borges, 2015), the objective of this research is to analyse the diversity of cases and select those where designers took an interest for strengthening the artisans' jobs in the field of pottery and textiles. We found that both revitalised the identity and cultural tradition in their own countries, in a moment when craft seemed to drop in front of industrial production. By preserving traditional materials, pieces continue to be unique and customizable, transcending thus their local origin towards new global markets.
\end{abstract}

\section{Keywords}

Digital craft, Latin America, fabrication laboratories, artisan

\section{Introduction}

Since 2005, Latin America lives through two phenomena that impact in its contemporary architecture and design history: scripting and digital fabrication (Herrera, 2010), as well as the production between designers and artisans (Duque et al., 2005, p. 11). At the beginning of the $21^{\text {st }}$ century in Europe reappears the interest on "ideas about craft in post-industrial societies" (Ferris, 2009, p.i) and "the revival of crafts has proved very promising in Latin America?" (Borges, 2015, p. 14). If we take into consideration "the uniformity and standardisation of industrial products, craft products are never identical" (Borges, 2015, p. 14), digital fabrications reinforces Borges' appreciation, since the cost of a part or component "is based on the machine's time, not shape or variety of parts, so there is no surcharge for complexity or difference" (SHoP, 2012, p. 251).

Craft and digital technology were systematically documented since 2009 in Making Futures, in conferences that explore craft as a change agent in $21^{\text {st }}$ century society. These researches represent a trend associated to two types of users. The first type was defined by Ferris (2013) as specialized and linked directly or indirectly to the maker movement; the second type is non-specialized and professionalized their practice in "a story of grass roots DIY, feminist 'craftivists', voluntary material simplicity advocates, and allied campaigners for local recycling and make and mend. All buoyed by broader alternative initiatives like the transition movement, urban farming, local markets and craft fairs, and reaching out to new audiences through internet websites, blogs, Facebook interest groups, and YouTube." (p. 3)

In architecture and design there are exemplary cases presented in ACADIA (Feringa, 2012), CAADRIA (Senske, 2014), ICDHS (Kipöz and Himam, 2014) and SIGraDi (Cardoso, 2009; Naboni and Breseghello, 2015). Bunell $(1998,2004)$ also documented the integration of CAD-CAM technologies in ceramics with experiences carried on the end of the $20^{\text {th }}$ century in PhD theses and works by professors associated to European universities. These cases identified the CAD software and devises utilized, such as CNC, Laser and 3D printer applied to ceramics, fabric and jewelry industries. Feringa (2012) points out "the artisanal inclination of digital craft can be explained partially by the highly involved process of moving from form toward fabrication" (p. 384). This is a tendency that will bring the first implementations to Latin America (Sperling et al., 2015).

Artisan and craft In Latin America

Oxford Dictionary defines artisan as "a worker in a skilled trade, especially one that involves making things by hand". 
Craft and technology in USA and Europe are different as in Latin America, as explained by Borges (2015): "In Northern countries, craft techniques are learned in university courses and are practiced by educated people who see in this activity a form of self-expression (...). In Latin America, it is an activity disseminated mainly throughout countryside areas, but also favelas and fringe areas in the cities, where the artisans make objects collectively as a way of coping with adverse conditions." (p. 11). This production has always been "purchased by people who wanted inexpensive items mainly because of their use value, or they were bought by intellectuals, professionals and tourists" (Vargas-Cetina, 1999, p. 303). The most remarkable problems run through the region, because "there is a difficulty to access digital platforms," (CNCA, 2010, p. 36); "the applied technology level in products and processes is limited, there is opposition to capacitation, to applying what has been learned and to modify the words, adding the difficult access to Internet." (DIRCETUR Puno, 2013, p. 23).

With a post-colonial history since the 18th century and popular arts' traditions, craft in Latin America is an "economic and cultural activity, destined to the elaboration and production of goods, entirely by hand or using hand-tools, or even mechanical means, using in site materials and related to a production place." (Organizacion de Estados Americanos [OEA], 1973). This definition was used by the Concejo Nacional de la Cultura y las Artes [National Council of Culture and Arts] in Chile (CNCA, 2010), by law 13.180 (2015) in Brazil and by law 29073 (DOP, 2007, p. 349898) in Peru through the Ministerio de Comercio Exterior y Turismo [Ministry for Foreign Trade and Tourism], which recognizes the artisan as a builder of identity and cultural tradition. This legal formalization from the $21^{\text {st }}$ century does not specify the incorporation of technologies different to mechanical ones, with initiatives for technologies in making and learning inside state training centers. A different case is the proposal of the Ministerio de Comercio, Industria y Turismo [Ministry for Trade, Industry and Tourism] in Colombia, which creates in 1964 Artesanias de Colombia [Colombian Crafts]. (Duque et al., 2005, p. 70). This country officially defined the profession of the artisan with law 36 (1984) and at the end of 1990s historically linked the work of designers and artisans in programs such as Laboratorio de Diseño [Design Lab] aiming to innovate and improve with technology, research and develop products and enhance human talent. The promoted "computer-aided design methodology, based on the horizontal interaction between the artisan and the designer, permits the stimulation of the artisan's creative processes. It also allows during the practical session for alternatives of the product to be visualized and conceptualized, facilitating the artisan's imagination to create and recreate." (Duque et al., 2005, p. 73).

\section{Methodology}

Scientific production on digital fabrication in Latin America, between 2004 and 2014, represent 11\% of the world total (Luli and Minto, 2015, p. 425). However, there are practice cases outside academia, not accounted for. That is the case of non-profit professional experience and FabLabs sponsored by MIT. Craft for these groups became a pretext for applied exercises and the application of material and shape. From a historic classification of implementations (Herrera and Juarez, 2013) and an exhibition that joined 31 digital fabrication laboratories in six Latin American cities (Sperling et al., 2015), we selected only cases where designers and artisans combined their experience.

\section{Case studies}

Borges (2015) sustains there is not a recipe to revitalization of craft, nor results will be attained by verifying and analyzing from a comfortable distant office with air-conditioned. He proposes analysis in direct contact with place and people, inside the workshops where products are developed, considering Improvement of Technical Conditions, Use of local Materials, Identity and Diversity, Branding, Artisans as Suppliers and Combined Actions. We identify cases compliant with these conditions (p. 59).

Industrial design could have been the first link with craft, but it was architecture instead, triggered by the coming back of masters and PhD students to their countries of origin. They had the chance of experimenting with fabrication equipment, accessing a knowledge that they later applied in craft, in self-managed experiences developed in academic and professional contexts.

\section{Fab Academy}

Fab Academy is an education program created at MIT to promote digital fabrication. In 2009, it launched a call that works since 2010. Peru was the first country in Latin America to apply the program with help from the Govern of Spain (Herrera and Juarez, 2013). This program identifies two study cases, in Peru and Mexico, related with artisanal weaving. 


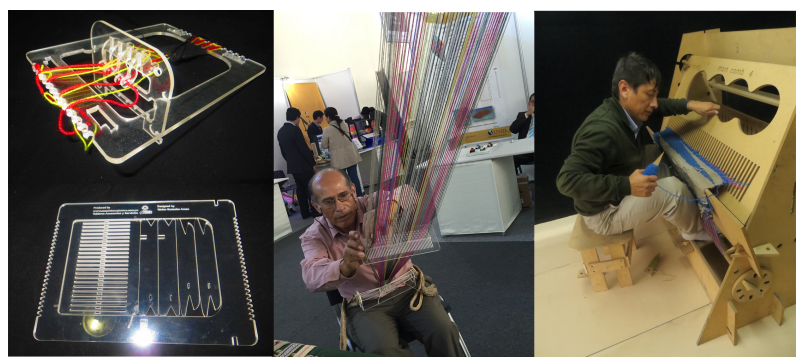

Fig. 1: Left: Mini Loom. Center: Artisan Oscar Salome using Improved Andean belt loom. Right: Walter Gonzales using Pedal Loom
In 2012, in FabLab UNI, architect Walter Gonzales Arnao fabricated a loom with the premise of reducing budget and time for production. Known as fabable loom (can be made in a FabLab), this machine can be built in an hour and costs around US $\$ 100.00$. It was tested in a weaving class in the School of Architecture at UNI in 2011. Gonzales' projects were also part of education programs, like project Fab Loom developed in MediaLab Prado [Madrid, 2014]. This workshop worked like an open sourced platform through Global Fab Awards at Fab10. The idea at MediaLab Prado was to replicate the loom in various

FabLabs in Spain. This workshop was directed by Gonzales and three of his designs were built: mini-loom (made with acrylic and laser cut), the belt-loom and the pedal-loom ( 9 pieces of pressed paperboard joined and cut using a CNC milling machine, optimizing up to a $60 \%$ the traditional loom, which uses several materials and is made of around 30 pieces).

In 2014 Gonzales was awarded the Diseño para el Desarrollo [Design for Development] award for his "pedal-loom and his didactic hand-loom" and for creating a technology aiming to improve the living conditions of people in vulnerable or poverty situations, according to the bases of the 4th Ibero American Design Biennial in Madrid. In October 2015, this invention was registered in Peru as a utility model, under the name telar de cintura andino mejorado [improved Andean belt loom]. Different variations of the product were used by artisans such as master Oscar Salome Rojas (Figure 1), known as Outstanding Personality in Culture in 2015 for his contributions to research in belt loom.

In 2013, in FabLab Mexico, architect Gonzalo Pérez took an interest in the impoverished community of women in the state of Chiapas, devoted to weaver. The short duration of FabAcademy limited the original project of a weaving machine. This case is one of many with a social agenda that can make an impact in society. However, transition to reality is complicated because of the several technical problems the participant has to face, since they are not specialists in the chosen problem, mixed with having to learn a new production technique. Best-case scenario, the results allow us to understand the nature of the process, although it is not always the same.

\section{Great things to people (gt2P)}

Using DIY 3D printers in pottery has some years. Jonathan Keep (b.1958) has said in different conferences, "the form is in the code". Keep (2016) explains that "digital computation is offering very new ways of generating ceramic form and that with time this 'new' will become part of tradition. Pottery has always reflected the technology of its time so for me it makes absolute sense to generate my work in computer code and then make it using 3D printing tech-

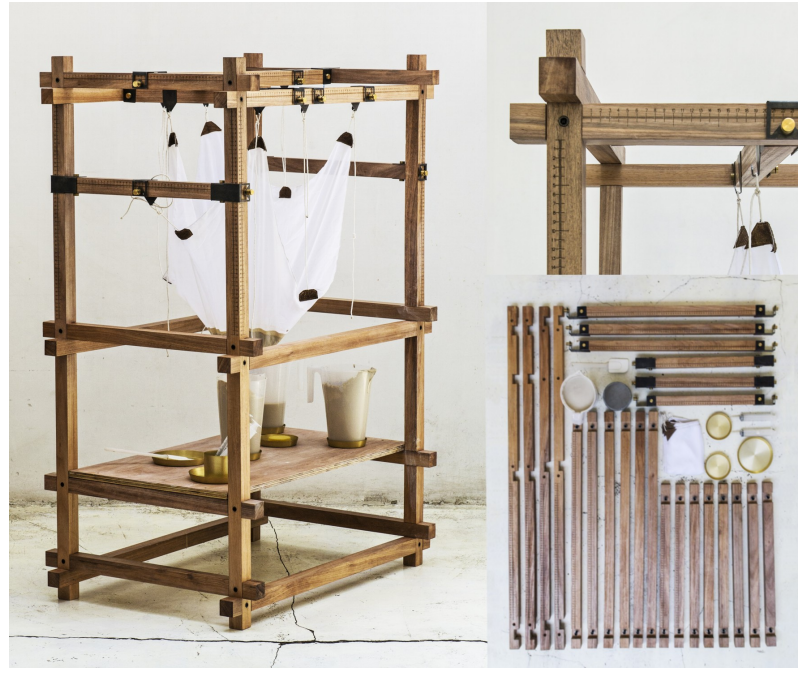

Fig. 2: Catenary Pottery Printer by gt_2P nology" (para. 6).

In Latin America, Great things to People (gt_2P) has a proposal that goes beyond code, fabrication and art. gt_2P is a parametric design and digital fabrication study born in Chile in 2009 by an initiative of Guillermo Parada (b.1981), architect and student of the first scripting workshop at Universidad de Chile in 2006. With the project "catenary pottery printer" (2013) in Figure 2, they come close to parametric non-digital experimentation, introducing the term digital crafting. "This means mixing digital technology (data managing, systematization of variables, digital production) and traditional techniques (handmade, traditional industry, local procedures, local materials)" (Rosso, n.d.). Their work system includes generative algorithms in architecture, art and design projects, which facilitates scaling to different products. They create the DNA to develop families of objects with parametric rules that allow the costumer to decide on the design of each product. They sustain that the produced ceramic objects are based on the idea of computer-aided craft (Figure 3). 


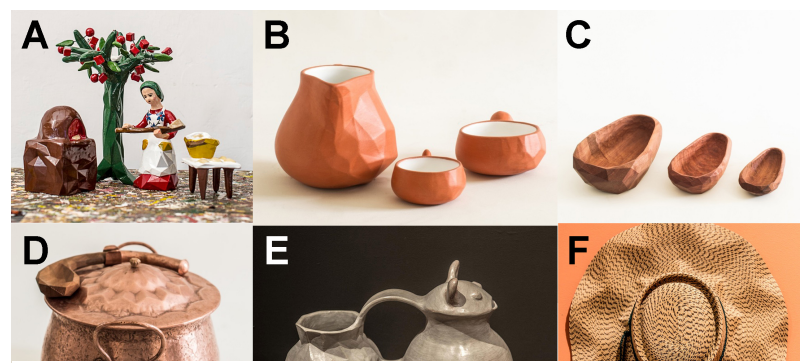

Figure 4: gt2P with the artisans A. Teresa Olmedo (ovenera). B. Vicson (red ceramic). C. Nestor Miranda (wood carving). D. Juan Orellana (olla cooper). E. Manuel Gonzalez (guaco). F. Juanita Muñoz (chupalla).

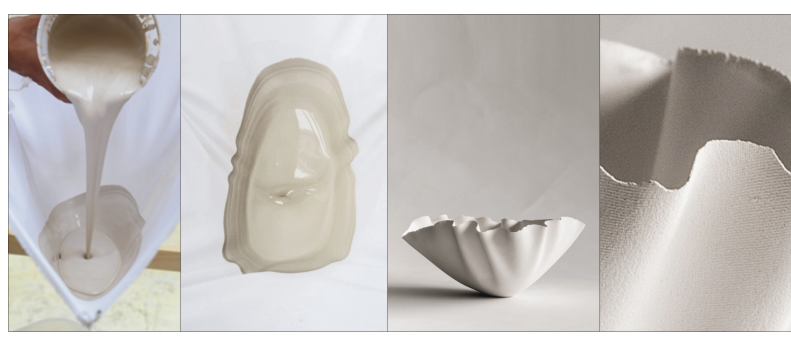

Figure 3: Pottery samples by gt2P.
gt_2P (2014) explain that "the Collection Losing my America born with the goal of identifying and cadastre techniques and artisans with a high sociocultural and economic value, who have the potential to collaborate with designers through the exchange of knowledge in practice, seeking to systematize the craft work techniques and strengthen their local economies." (para. 1). It is not casual that this collection was exhibited at Museum of Arts and Design in New York in 2014 (Figure 4). Architects no longer linked to gt_2p continue to apply digital crafting, like Juan Pablo Ugarte at GSD Harvard (n.d.), "who explore how artisanal creative and productive logics can help produce digital design and fabrication workflows where the material domain informs design more actively".

\section{Conclusion}

This research highlights three cases where, contrary to the idea of craft tradition seeming to fall in front of industrial production, the opposite occurs through participative initiatives and methods. When preserving the use of

traditional materials, pieces are still unique and, at the same time, personalized by final users.

On one hand, digital fabrication was used not just to automatize processes but also to maintain the traditional character of the object and the improvement of the technique, with results that could change contemporary design history in the region while encouraging local traditions.

On the other hand, scripting and programming guided by specialists allowed the permanence of the design process in code lines, common to all designers familiar to scripting, or to Rhinoscript or Python for writing programming, or Grasshopper or Dynamo, for visual programming. Under this work process, there is a memory of the shape of the object and a conservation of the tradition of representation and future modifications. We also identified that designers and artisans restored identity and cultural tradition, without losing originality in their proposals. This opens possibilities in a sector that refused to cross the limits of using traditional instruments.

China, Mexico and Peru represent three of the ten major producers of silver in the world, each of them surpassing the 100 million oz. of annual production. However, in Peru, in 2014 just $1 \%$ of said production is used in jewelry, according to the Export Association. As with other statistics linked to craft, this is an example of how jewelry has opportunities of implementation according to its vastness. Case studies show methods that could be used in other contexts, especially in emergent populations. Digital fabrication in Latin America finally finds roots of its own that enforce identity and culture and that were in risk of getting lost through urbanization and migration flows to cities. This enforcement, however, cannot happen if memory stays with the object. gt_2P has demonstrated that programming and scripting perform flexible not only changes, but the whole process until the final product. Since in Latin America the use of emergent technologies has been researched from academia and not from practice, as in the northern hemisphere (Leach and Yuan, 2012:9), the effect of using programming and digital fabrication in Latin American architecture schools allowed for students' initiatives to grow aiming to improve the lives of others without the excessive cost of previous years. This reduces investment in new equipment, using instead ones personalized to the needs of both producer and market. This gives the artisan more time to devote to creative process and directly giving more value to their products.

\section{References}

Borges, A. (2011) Design + Craft. The Brazilian Path, Sao Paulo: Editora Terceiro Nome.

Borges, A. (2015) Craft revitalisation as a change agent in Latin America. Making Futures Journal. Retrived from http://www.plymouthart.ac.uk/documents/Adelia_Borges_-_Keynote.pdf

Bunnell, K. (2004) Craft and Digital Technology, World Craft Council 40th Annual Conference, Metsovo, 
Greece.

Bunnell, K. (1998) The Integration of New Technology into Ceramic Designer-Maker Practice, PhD Thesis published on CDROM, The Robert Gordon University, Aberdeen

Cardoso, D. (2009) Generative Craft. A brief critical inquiry into design automation and design automata, 13th SIGraDi, pp. 288-290. Sao Paulo.

Concejo Nacional de la Cultura y las Artes. (2010) Política de fomento para la artesanía, 2010-2015, Valparaíso, Chile.

Diario Oficial el Peruano, (2007) Ley 29073 del artesano y del desarrollo de la actividad artesanal, Lima, Perú.

Dirección Regional de Comercio Exterior y Turismo - Puno (2013) Plan operativo institucional.

Duque, C., Sethi, R. and Vencatachellum, I. (2005) Designers meet Artisans. Craft Revival Trust. New Delhi, India.

Feringa, J. (2012) Implicit Fabrication, Fabrication beyond Craft, The potential of turing completeness in construction. Synthetic Digital Ecologies: ACADIA 32, pp. 383-390. San Francisco: California College of the Arts,

Ferris, M. (2009) The Crafts in the Context of Emerging Global Sustainability Agendas, Making Future Journal, vol. 1. Retrived from

http://mfarchive.plymouthart.ac.uk/journalvol1/papers/Making\%20Futures\%20Paper\%20Editor\%20Introduct ion.pdf

Ferris, M. (2013) The returns of Craft in a Post-Global Sustainably Aware Society, Making Future Journal, vol. 3. Retrived from

http://mfarchive.plymouthart.ac.uk/journalvol3/assets/making_futures_editors_introduction_by_malcolm_ferr is.pdf

gt_2P. Great things to People (2014). Losing my America. Retrived from http://www.gt2p.com/Losing-myAmerica-1

GSD Harvard (n.d.). Doctoral Programs. Student Profiles. Retrived from

http://www.gsd.harvard.edu/\#/academic-programs/doctoral-programs/ddes/student-profiles.html

Herrera, P. (2010) Disruptive Technologies: Scripting and Digital Fabrication in Latin America, 14th SIGraDi, pp. 213-216. Bogotá.

Herrera, P. and Juarez, B. (2013) Fabrication Laboratories: Problems and possibilities of implementation in Latin America, Fab9 Research. Yokohama.

Keep, J. (2016) The Form is in the Code, Ceramics and New Technologies Symposium. Retrived from http://www.holburne.org/planning-your-visit/whats-on/talks/ceramics-symposium-abstract/

Kipöz, Ş; Himam, F (2014) Re-Inventing Traditional Textiles For The Contemporary Design Culture, 9th ICDHS, pp. 439-444. Sao Paulo.

Leach, N. and Yuan, P. (2012) Scripting the Future, Shanghai: Tongji University Press.

Luli, E. and Minto, M. (2015) Digital Fabrication in Brazil. Academic production in the last decade. In Celani, Sperling, Franco (Eds.) 16th International Conference CAAD Futures 2015, pp. 421-433. São Paulo.

Naboni, R.; Breseghllo, L. (2015) Weaving Enclosure. Material computation and novel forms of Crafting, 19th SIGraDi, pp. 384-391. Florianopolis.

Organización de Estados Americanos (1973) Carta Interamericana de las Artesanías y las Artes Populares, Washington D.C.

Rosso, A. (n.d.) Digital Crafting with gt2P Chilean Collective. Retrived from

https://artemest.com/magazine/new-vision/gt2p-digital-crafting

Senske, N. (2014) Digital Minds, Materials, and Ethics: Linking Computational Thinking and Digital Craft, 19th CAADRIA, pp. 841-850. Hong Kong.

SHoP (2012) Shop Out of Practice, New York: Monacelli Press.

Sperling, D.; Herrera, P.; Scheeren, R. (2015) Migratory Movements of Homo Faber: Mapping Fab Labs in Latin America, CAAD Futures 2015, pp. 405-421. Sao Paulo.

Vargas, G. (1999) 'Flexible Looms: Weavers' Organizations in Chiapas, Mexico', Urban Anthropology and Studies of Cultural Systems and World Economic Development, vol. 28, August, pp. 299-325.

\section{Biographical note}

Pablo C. Herrera develops academic activities incorporating emerging technologies in Latin America. Since 2004 he has been part of scientific committees in 29 conferences around the world, belonging to 9 different associations. He has published 23 papers on the result of his research on computational design solutions using scripting, textual and visual programming, including digital fabrication. ACM Senior Member, President of the Sociedad Iberoamericana de Gráfica Digital (SIGraDi), Co-Chair of the exhibition Homo Faber: Digital Fabrication in Latin America and recipient of the Arturo Montagú Award for his outstanding contribution to SIGraDI. Guest Editor for the International Journal of Architectural Computing (IJAC). 